\title{
ESTIMATE THE ANNUAL SOIL LOSS IN KUMMATTIPATTI NADI WATERSHED USING RUSLE MODEL THROUGH GEOSPATIAL TECHNOLOGY
}

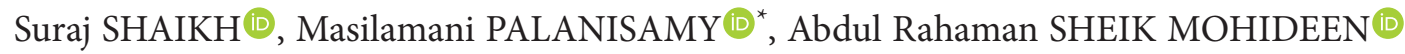 \\ Department of Geography, Bharathidasan University, Tiruchirappalli, India
}

Received 15 October 2019; accepted 03 June 2020

\begin{abstract}
Soil erosion and soil loss is one of the common problems threatening the environment. This degrading phenomenon declines the soil fertility and significantly affects the agricultural activity. As a consequence, the productivity of soil is affected unquestionably. In this reason, there is a basic need to take up conservation and management measures which can be applied to check further soil erosion. Even though, soil erosion is a mass process spread cross the watershed, it is not economically viable to implement conservation techniques to the entire watershed. However, a method is a pre-requisite to identify the most vulnerable areas and quantify the soil erosion. In this study, Revised Universal Soil Loss Equation (RUSLE) has been accepted to estimate soil erosion in the Kummattipatti Nadi watershed part of the Coimbatore district of Tamil Nadu, India. This model has several parameters including runoff-rainfall erosivity factor (R), soil erodability Factor $(\mathrm{K})$, topographic factor (LS), cropping management factor (C), and support practice factor (P). All these layers are prepared through geographical information system (GIS) by using various data sources and data preparation methods. The results of the study shows that the annual average soil loss within the watershed is about $6 \mathrm{t} / \mathrm{ha} / \mathrm{yr}$ (metric ton per hectare per year). Higher soil erosion is observed in the land use classes of gullied wasteland, open scrub forest and degraded plantation. The soil erosion risk is extremely higher on the steep slopes and adjoining foothills. The proper conservation and management strategies has to be implement in this watershed for the development.
\end{abstract}

Keywords: soil erosion, soil loss, erosivity, erodability, erosion risk, RUSLE, remote sensing and GIS.

\section{Introduction}

Soil is an essential for all vegetation and plantation. Today soil erosion is the burning issue and threat to the environment. This degrading phenomenon declines the soil fertility and drastically affects the downstream reaches. Thus, the productivity is affected unquestionably. In this concern, there need to be conservation and management measures which can be applied and a check on soil erosion can be done. But soil erosion is a mass process spread across spatially and it is not economical and viable to implement conservation techniques to all the regions. This study method is a pre-requisite to identify the most vulnerable areas and quantify soil erosion. There are several studies has be conducted by using Revised Universal soil Loss Equation (RUSLE) model at global level because of its simple methodology. Therefore, the RUSLE model has been used to assess soil erosion in the study area.

Balasubramani et al. (2015) using revised universal soil loss equation (rusle) model through GIS. The study indicates that the annual average soil loss semi-arid watershed of Tamilnadu the watershed is about $6 \mathrm{t} / \mathrm{ha} / \mathrm{yr}$. (Metric ton per hectare per year). Higher soil erosion is observed in the land use classes of gullied wasteland, open scrub forest and degraded plantation. The soil erosion risk is extremely higher on the steep slopes and adjoining foothills. Based on the average. Rahaman et al. (2015) estimation of annual average soil loss, based on RUSLE model in kallar watershed, Bhavani basin, Tamil Nadu, India in this study soil erosion is a widespread environmental challenge faced in Kallar watershed now a days. Erosion is defined as the movement of soil by water and wind, and it occurs in Kallar watershed under a wide range of land uses. Erosion by water can be dramatic during storm events, resulting in washouts and gullies. Soil erosion assessment for watershed management is a world- wide concern for ecologists and land users. Revised Universal Soil loss Equation was used to estimate the sediment load in the Lo River basin and to

*Corresponding author. E-mail: masilamani@bdu.ac.in 
find the effect of land use on the soil loss. Here, Ranzi et al. (2012) found that the impoundment of two large reservoirs at the BA and Tuyen Quang, in the Chay and Gam river basins has resulted in a considerable reduction of the measured total suspended load with a sediment load reduction of about $95 \%$ and $71 \%$, respectively.

Parveen and Kumar (2012) studied the south Koel Basin, Jharkhand by the integrated approach of USLE and GIS. They had classified the area, according to the soil erosion risk and accordingly priority zones for conservation purposes were recommended. Sharma et al. (2011) used USLE to determine the influence of land use and land cover change (LULC) on soil erosion potential of a reservoir catchment during the period 1989 to 2004. Results showed that the mean soil erosion potential of the watershed was increased slightly from $12.11 \mathrm{t}$ ha- 1 year -1 in the year 1989 to 13.21 tha-1year-1 in the year 2004 .

Dabral et al. (2008) assessed the North Eastern Indian hilly catchment using USLE, GIS and Remote Sensing. About $25.61 \%$ of the watershed area was found out to be under slight erosion class. Areas covered by moderate, high, severe and very severe erosion potential zones are $26.51 \%, 17.87 \%, 13.74 \%, 2.39 \%$ and $13.21 \%$ respectively. Therefore, the areas which needed immediate attention from the soil conservation point of view were identified spatially. Yang et al. (2003) studied the global potential soil erosion with reference to land use and climate changes. Their study employed a GIS-based RUSLE model to simulate global soil erosion. It potential soil erosion of present global potential soil erosion, examined historical changes of potential soil erosion in the last century, and projected future conditions for 2090 under global changes in climate and land uses. Present soil erosion potential was estimated and predicted that the Southeast Asian region is the most prone region to soil erosion. This large amount of soil erosion is caused by, and is causing, many floods and other environmental problems. Angima et al. (2003) used RUSLE for the highlight the severity of erosion in the tropical highlands of East Africa. The primary objective of their study was to develop a database for use in predicting erosion rates in the Kianjuki catchment in central Kenya. Also, RUSLE proved to be a useful tool for determining erosion hazards in the region and pinpointed areas that would benefit meaningfully from intervention strategies.

\section{Aim and objectives}

The main aim of the study in the Kummattipatti Nadi watershed is to estimate the average annual soil loss using the Revised Universal Soil Loss Equation (RUSLE) model and to find out the most endangered regions which should be given preference for conservation practices and management to be carried out. In this study following objectives are selected.

- To find out and evaluate the deciding parameter of the RUSLE model.
- To prepare the corresponding maps and overlay them using ArcGIS.

- To estimate the average annual soil loss in the study area.

\section{Study area}

A Kummattipatti Nadi watershed area comes under the Coimbatore District, Tamil Nadu. It is located in the South Coimbatore this extends between the latitudes $10^{\circ} 47^{\prime} 22^{\prime \prime}$ and $10^{\circ} 57^{\prime} 45^{\prime \prime}$ East and the longitude of $76^{\circ} 45^{\prime} 10^{\prime \prime}$ and $77^{\circ} 1^{\prime} 40^{\prime \prime}$ north. This Watershed covered an area of 264.39 Sq. km. The Location Map is shown in Figure 1.

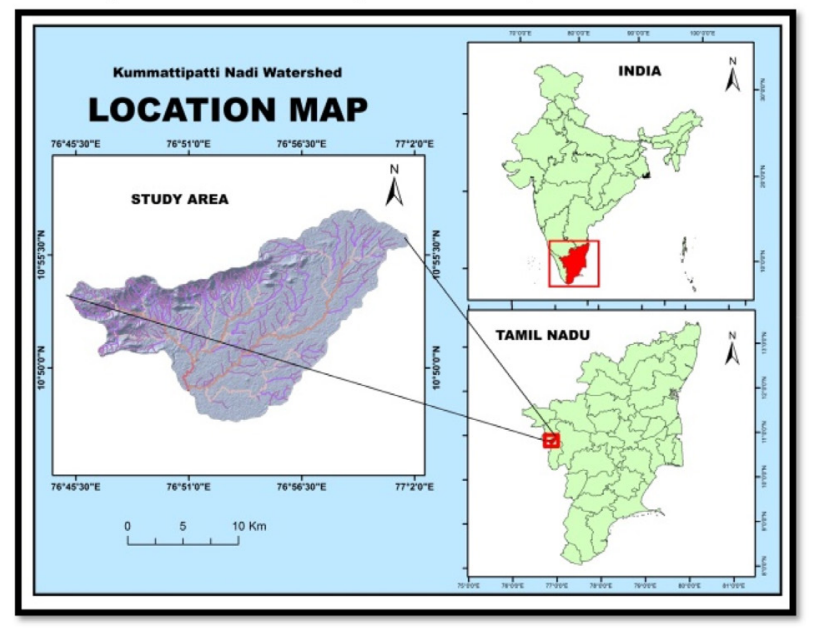

Figure 1. Study area

Geologically in this area is made up of rocks of Dharwar age, followed by Charnokites, Peninsular gneiss and youngest intrusive. The Dharwars are represented by rocks like chlorite schist, garnet ferrous quartz, schistose, quartzite's and gutsy magnetite schist. The mineral wealth of the district is not insignificant. Limestone is found in abundance in the hills near Madukkarai. This situated near to the south of Coimbatore town. Good quality mica is found in the upper part of the study area. Geomorphologically study area, west and northwest parts covered with structural hills (Figure 2a). This area has few cliffs and escarpments. This study area covers the alluvial fan in central and foothills of the study area. These areas mostly cover the Denudational Origin-Pediment-Pedi Plain Complex and dominated role. River area was much planned and mostly covers the agriculture sector.

Kummattipatti Nadi watershed area under the Coimbatore district in the western part of Tamil Nadu, and bordering the state of Kerala. It is surrounded by the Western Ghats mountain range on the west and north. The temperature ranges between $18.32{ }^{\circ} \mathrm{C}$ in the month of January and $36.42{ }^{\circ} \mathrm{C}$ in the month of April. In this study area main River is Kummattipatti Nadi this origin at Etti Malai hills. The drainage pattern is dendritic. All streams flow to the south and southern direction and meet the Valayr River (Figure 2b). High drainage 

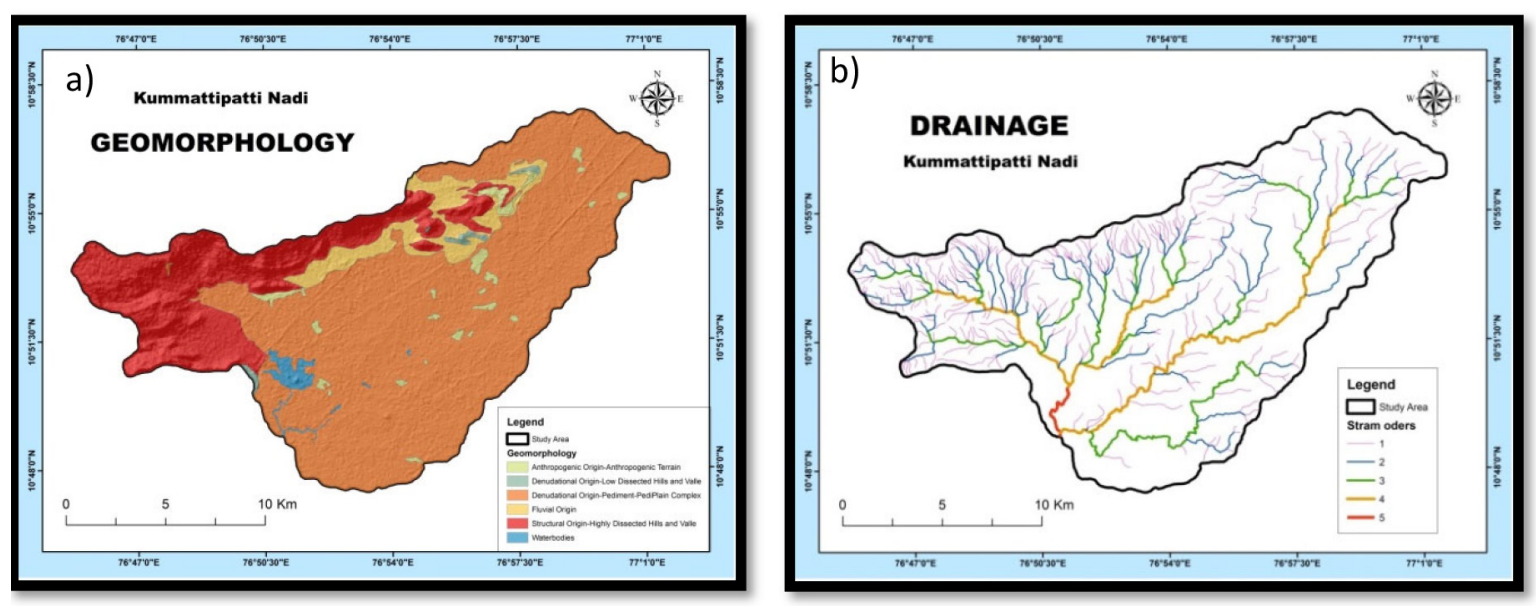

Figure 2. a) Geomorphology; b) Drainage

density has the north western side of the study area. The watershed has divided into subdivides two small watersheds. The Kummattipatti Nadi watershed has been further classified into two watersheds which are namely 1) Walayar watershed, 2) Kummattipatti Nadi watershed. This area main occupation is agriculture because of this river provide the irrigation facility. Also this area has one reservoir in the south part.

In this study area showed a gradual decrease in slope from the north to south direction (Figure 3a). Structural hills are moderately sloping along the north to the northeast part of the study area. The riverside area is almost flat and covers the major part of the study area. Land use / land cover classification using the LISS IV Image with the spatial resolution of 5.8 meters. Study area, mostly comprises of agricultural fields, both irrigated also non irrigated means rain fed. The area has scattered settlement and some part is compact settlement. Mudukkarai and Podnur are the major towns in the area and those are well connected by transportation network. North and northwest part of study area covered with forest land (Figure $3 \mathrm{~b})$. Apart from these, large areas of wasteland and follow land are under uncultivated.

\section{Database and methodology}

The degradation of the environment through soil erosion is a significant concern for analyzers. Analyzer's mostly use the RUSLE. This is a quantitative evaluation of soil erosion loss. This model based on its component factors corresponding to each of the parameters of the equation. This study required data provide the primary and secondary source. The rainfall data were acquired from the state surface and ground water resource data center, Chennai. Using this data calculates the average annual rainfall and prepared the Rainfall ( $\mathrm{R}$ factor) map. The $\mathrm{k}$ factor proposes using the soil data. This data provide the National Bureau of Soil Survey, Nagpur, and then find out the (K Factor). Next factor using the satellite imageries LISS-IV, Landsat, which sensor characteristics are given following these images used to prepare a level-III Land use, land cover classification based on NRSC classification to identify the supporting the conservation practice (P Factor) and using the Landsat image calculate the NDVI to identify the cropping management factor (C Factor). Cartosat DEM used to generate the slope and prepared the slope length and slope steepness (LS factor). The detailed methodological workflow is shown in Figure 4.
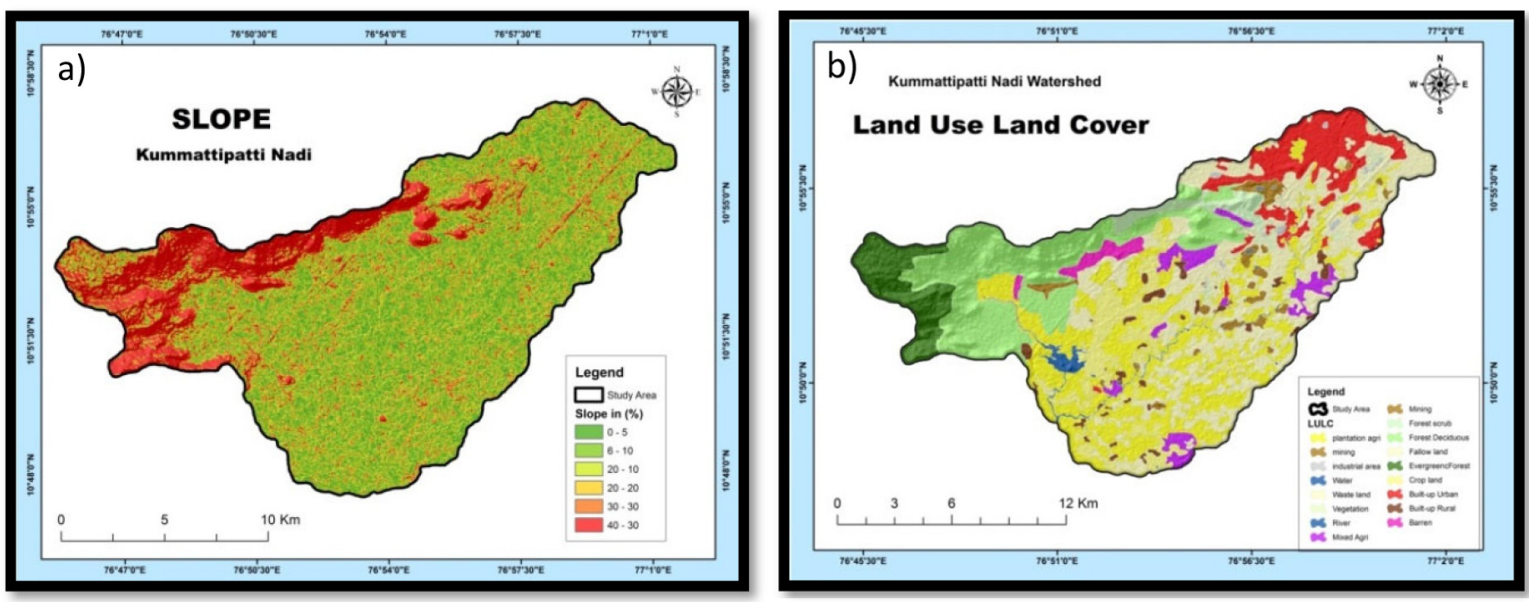

Figure 3. a) Slope; b) Land use 


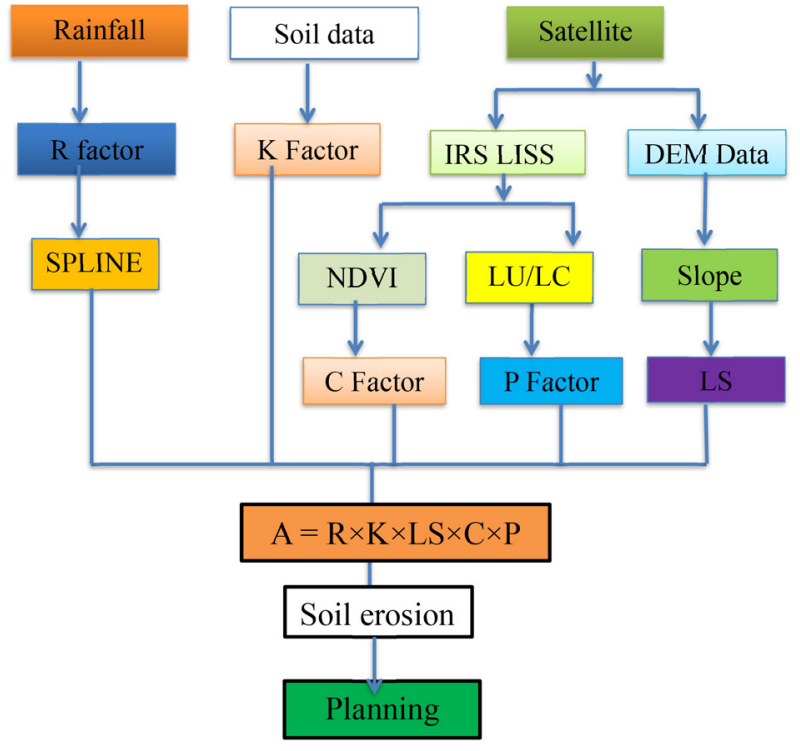

Figure 4. Work flow of RUSLE

The emergence of soil erosion models had enabled the study of soil erosion, especially for conservation purposes, ineffective and acceptable level of accuracy. To estimate soil erosion and to develop optimal soil erosion management plans, many erosion models, such as universal soil loss equation and revised universal soil loss equation (USLE/RUSLE), water erosion prediction project (WEPP) etc. Vijith et al. (2012); Prasannakumar et al. (2012).

The RUSLE had been generally used for both agricultural and forest watershed to predict the average annual soil loss by introducing better means of computing the soil erosion factors (Wischmeier \& Smith, 1978; Renard et al., 1996). RUSLE model has the equation as follows:

$$
A=R \times K \times L S \times C \times P,
$$

where: $A$ - estimated average soil loss in tons per hec per year; $R$ - rainfall-runoff erosivity factor; $K$ - soil erodability factor; $L$ - slope length factor; $S$ - slope steepness factor; $C$ - cover-management factor; $P$ - supporting conservation practice factor.

\section{1. $R$ = rainfall-runoff erosivity factor}

$R$ is the rainfall and runoff erosivity index required to predict erosion by water using the RUSLE. ' $R$ ' is the Average annual sum of all erosive rainfall events (EIs). Rainfall kinetic energy and the maximum rainfall intensity in $30 \mathrm{~min}$ in $\mathrm{mm} /$ per/hour (Wischmeier \& Smith, 1978). Rainfall intensity represents the principal factor of kinetic energy and to estimate the rainfall erosivity, several empirical methods have been developed for different regions of the world. The erosivity of rainfall varies greatly by location. In this study, the linear relationship established by Singh et al. (1981) and adopted by Parveen and Kumar (2012) was used to calculate the annual rainfall erosivity. The derived relationship is given below:

$$
R=79+0.363 R_{N},
$$

where $R_{N}$ is the average annual rainfall in $\mathrm{mm}$.
In this study, 35 years (1981-2014) average annual rainfall data had been used to calculate the average annual $\mathrm{R}$ factor values. This study area selected only for 11 rainfall gauge stations are located in and around the study area, station name and using the interpolation technique and derived the rainfall-runoff erosivity map (R-factor). After several attempts of trial investigations, SPLINE interpolation technique was adopted in this study. The erosivity factor varies from 87.95 to $139.12 \mathrm{MJ}$ ha/mm/hr./Yr.

\section{2. $K=$ Soil erodability factor}

This factor represents the rate at which different soils erode. Some soil types are naturally more prone to soil erosion due to their physical structure. Readability is a function of soil texture, organic matter content and permeability. A nomograph prepared by Wischmeier and Smith (1978) is widely used to predict soil readability factor. Generally, Soil erodability depends on soil and, or geological characteristics, such as texture, structure, parent material, organic matter, porosity, content, catena and many more (Schwab et al. 1993). Also, soils become of low erodability if the silt content is low, regardless of corresponding high content in the sand and clay fractions (Mhangara et al., 2012). In this study Soil texture map was extracted from soil survey data, Tamil Nadu was used for $\mathrm{K}$ factor. Major soil textural classes found in the areas are clay loam, clay, loamy sand, loamy, sandy clay, sandy clay loam, and sandy loam. The corresponding $\mathrm{K}$ values for the soil types were identified from the soil erodability nomograph (USDA1978) by considering the particle size, organic matter content, and permeability class. The estimated $\mathrm{K}$ values for the textural groups give the following Table 1.

Table 1. Soil Erodability Factor $\mathrm{K}_{\text {fact }}$ (source: Wischmeier \& Smith, 1978)

\begin{tabular}{|l|c|}
\hline \multicolumn{1}{|c|}{ Textural Class } & K Value \\
\hline Sand & 0.05 \\
\hline Loamy sand & 0.12 \\
\hline Sandy Loam & 0.37 \\
\hline Loam & 0.15 \\
\hline Sandy clay loam & 0.27 \\
\hline Clay Loam & 0.20 \\
\hline Sandy clay & 0.15 \\
\hline Clay & 0.28 \\
\hline
\end{tabular}

\section{3. $L S=$ Slope length and Steepness factor}

The (LS) factor expresses the effect of local topography on soil erosion rate, combining the effects of slope length (L) and slope steepness (S). Within RUSLE, slope length is considered by the $L$-factor, a sub-component of $L S$. Slope length is defined as the horizontal distance from the origin of overland flow to the point where either the slope gradient decreases to a point where deposition begins, or runoff becomes focused into a defined channel 
(Foster \& Wischmeier, 1974; Wischmeier \& Smith, 1978; Renard et al., 1996). The longer slope length the greater the amount of cumulative runoff. It was Also the steeper the slope of the land the higher the velocities of the runoff which contribute to erosion. GIS-based methods for calculating the $L$ and $S$ factors can be found in (Dunn \& Hickey, 1998) and (Hickey, 2000) and the explanations of separate methods could be found in Moore and Burch (1986), Desmet and Govers (1996) and Van Remortel et al. (2004). Using the USGS Aster DEM data with the grid cell size of $30 \mathrm{~m}$. DEM was processed to generate slope gradient and $L S$ factor maps. The average slope of each pixel (in percentage) was calculated from the greatest elevation difference between it and its eight neighboring pixels. The empirical equation developed by Wischmeier and Smith is done by following equation:

$$
L S=\left(\frac{L}{22.13}\right) m X\left(0.65+0.45 \times S+0.065 \times S^{2}\right),
$$

where: $L$ - slope length (meters); $S$ - angle of slope (percent); $M$ - constant value dependent on the slope gradient 0.5 if the slope angle is greater than $5 \%, 0.4$ on slopes of $3 \%$ to $5 \%, 0.3$ on slopes of 1 to $3 \%$, and 0.2 on slopes less than $1 \%$. To implement LS factor in Arc GIS, the below formula of Bizwuerk et al. (2008) was used.

$$
L S=\operatorname{Pow}\left(F A \frac{C S}{22.13}\right) 0.4 X\left(0.65+0.45 \times S+0.065 \times S^{2}\right),
$$

where: FA - Flow accumulation; CS - Cell Size.

Then calculate the slope length and slope steepness factor (LS) derived from ASTERGDEM data. First derived flow - accumulation and after that calculate LS factor. In This study LS factor derived are shown (Figure 6a) and the value range from 0 to 14.149 .

\section{4. $C=$ Cover management factor}

In the RUSEL model C factor represents the effect of surface cover and roughness on soil erosion. They are cover factor most common factor. This factor had been used to reflect the effect of cropping and management practices on erosion rates. The $\mathrm{C}$-factor indicates how the conservation plans will affect the average annual soil loss and how that soil-loss potential will be distributed in time during construction activities, crop rotations or other management schemes (Van der Knijff et al., 2000). Soil loss was very sensitive to vegetation cover with slope steepness and length factor (Renard \& Ferreira 1993; Benkobi et al., 1994; Biesemans et al., 2000). Vegetation that is actively growing represent a high reflectance in the Infrared portion of the spectrum (Band 4), compared with the visible portion (red, Band 3), thus the NDVI values for actively growing vegetation is positive. NDVI values for low vegetative surface cover range between -0.1 and +0.1 , while clouds and water bodies show a negative or zero values (Kouli et al., 2009). In this study shown high C factor values indicate more vulnerability to soil erosion, as they had been considered to be unprotected barren land and wasteland. In the present study, Normalized Difference Vegetation Index (NDVI) - based assessment of C factor was carried out by the equation:

$$
C=\exp \left[\propto \frac{N D V I}{(\beta-N D V I)}\right],
$$

where: $\alpha$ and $\beta$ are unit less parameters.

That determines the shape of the curve relating to NDVI and the C factor. Van der Knijff et al. (2000) found that this scaling approach gave better results than assuming a linear relationship, and the values of 2 and 1 were selected for the parameters $\alpha$ and $\beta$, respectively.

\section{5. $P$ = Supporting conservation practice factor}

In the RUSLE model P Factor derived from support practices. It is also known as the conservation practice factor. It was used for the effects of contouring and tillage practices on soil erosion and soil loss are described. Within the RUSLE model (Renard et al., 1996). The Supporting conservation factor $(\mathrm{P})$ relates to the practices which restrict water runoff and reduce the effective soil erosion. The $\mathrm{P}$ - value ranged from using the 0 to 1 , where the highest value is assigned to areas with no conservation practices. The value of $\mathrm{P}$ factor was normally determined by the method of cultivation and slope of the terrain (Shi et al., 2004).

Table 2. Supporting conservation practice factor range (source: compiled by the author)

\begin{tabular}{|l|c|}
\hline \multicolumn{1}{|c|}{ Land use / land cover } & P Value \\
\hline Built-up (Urban, Rural, Industrial) & 0 \\
\hline Water & 0 \\
\hline Forest scrub & 0.2 \\
\hline Mixed Agricultural & 0.5 \\
\hline Cropland & 0.5 \\
\hline Plantation Agriculture & 0.5 \\
\hline River & 0.7 \\
\hline Forest Deciduous & 0.7 \\
\hline Barren (Scrubland,) & 0.1 \\
\hline Fallow land & 0.9 \\
\hline Mining & 1 \\
\hline
\end{tabular}

\subsection{Limitation}

The study area consisted of numerous small parcels of land is a setback while preparing land use/land cover map. More reconnaissance of the field was required for better assigning of cropping management factor and supporting conservation practice since there was no standard cultivation technique followed, it again became a hindrance in assigning values and they were compromised to an extent. 


\section{Results and discussion}

\subsection{Rainfall and Runoff Erosivity Factor (R)}

The annual average rainfall was calculated using the data from 11 rainfall stations. Spatial interpolation technique was used to create a rainfall surface layer of the study area. Average annual rainfall varied between $51 \mathrm{~mm}$ to $232 \mathrm{~mm}$. Rainfall runoff erosivity map (Figure $5 \mathrm{a}$ ). Was generated in the Arc-GIS by using the annual average rainfall map, applying equation 1 . This rainfall runoff erosivity factor varied between 87.95-139.12 MJ ha/mm/hr./yr.

\subsection{Soil Erodability Factor (K)}

$\mathrm{K}$ factor used in the quantitative estimation of soil erosion gives the vulnerability to of terrain to get eroded. This factor depends upon the soil composition and soil texture. Major soil textural classes found in the area are clay loam, clay, loamy sand, loamy, sandy clay, sandy clay loam, and sandy loam. The matching $\mathrm{K}$ values for the soil types were identified from the soil erodability nomograph (USDA/1978) by considering the particle size, organic matter content, and permeability class. These estimated $\mathrm{K}$ values for the textural groups are shown in the Table 1. The soil erodability factor of the region is represented as a soil erodability distribution map (Figure 5b). In this area high soil erodability factor is at the center of the area because this area covers the clay soil which has highest $\mathrm{k}$ value (0.37).

\subsection{Slope Length and Slope Steepness Factor (Ls)}

This factor was estimated by using the cartosat DEM with 30 meter resolution. ArcGIS hydrology tools were used to calculate flow accumulation and slope, which were later used in the formula (3\&4) in the raster calculator to get the LS factor (Figure 6a). The value of LS factor ranges between 0 to 14.14 .

\subsection{Cover Management Factor (C)}

The $\mathrm{C}$ factor is used to determine the relative effectiveness of soil and crop management systems in terms of reducing soil loss. NDVI of the area was calculated using the formula (5) in order to derived the $\mathrm{C}$ factor (Figure 6b). The value of $\mathrm{C}$ factor ranges between 0.36 to 1 .
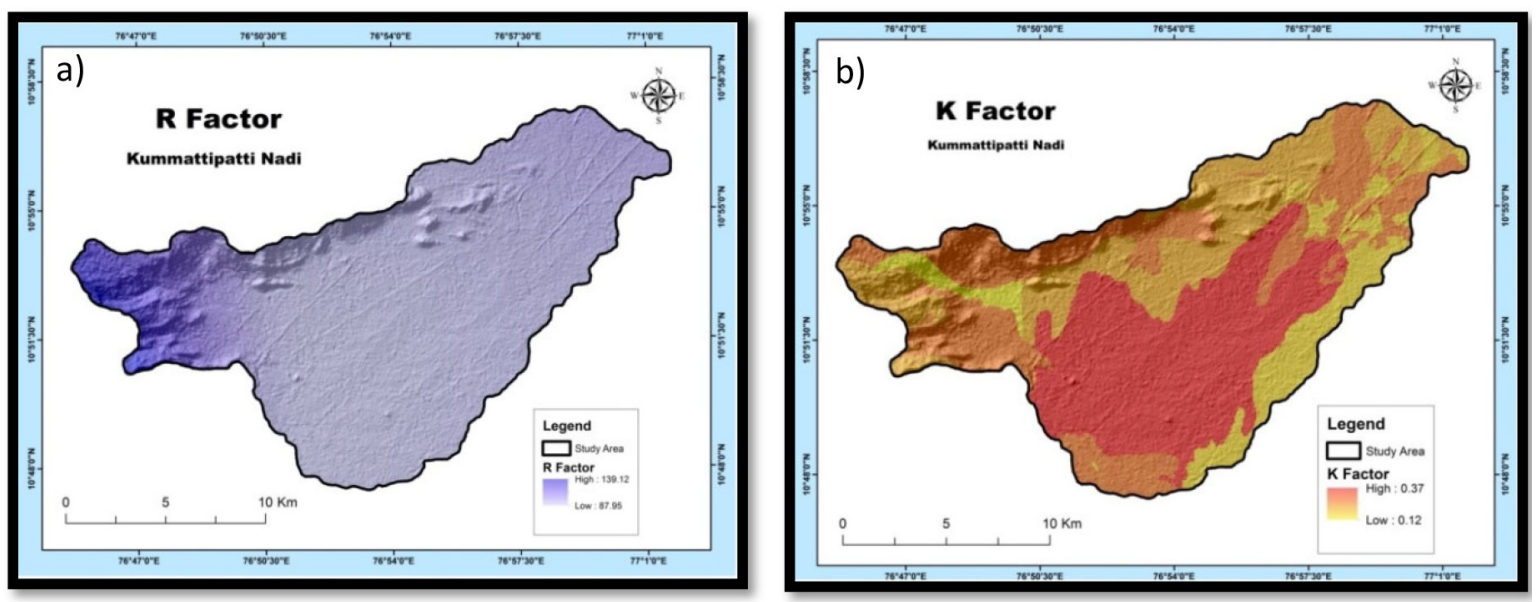

Figure 5. a) Rainfall Runoff Erosivity (R); b) Soil Erodability Factor (K)
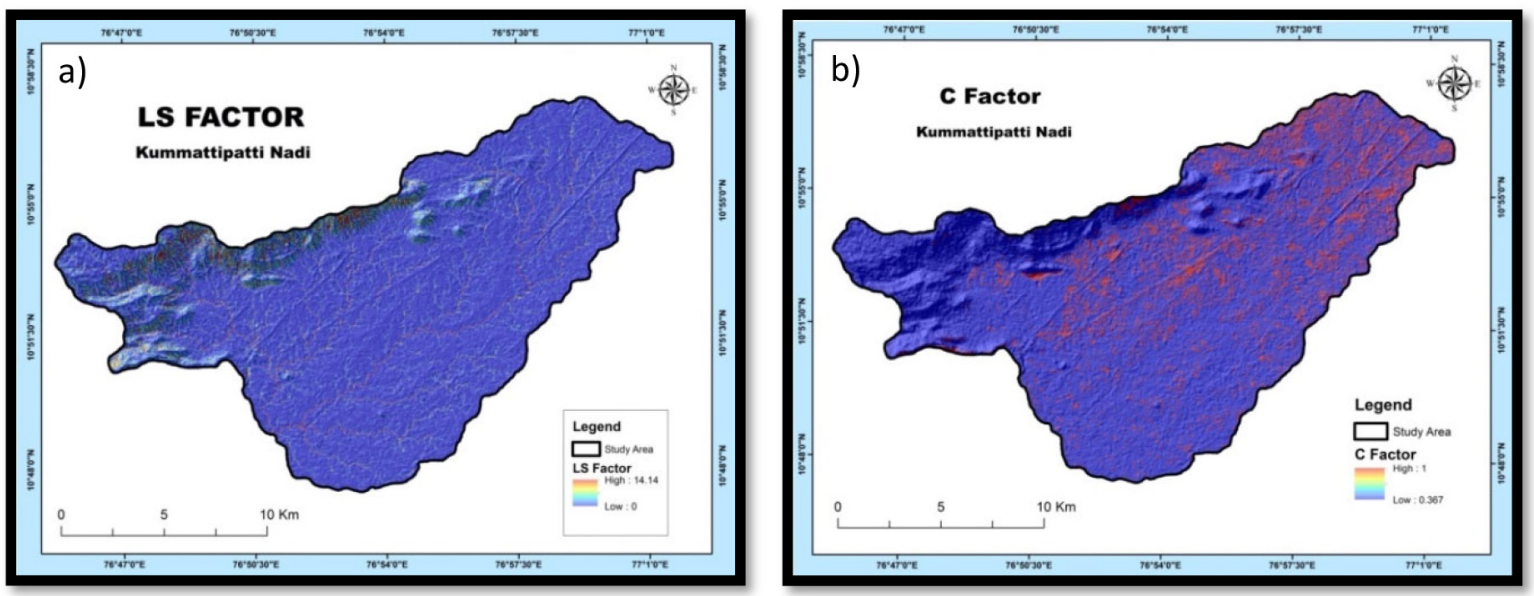

Figure 6. a) Slope Lengths and Steepness (LS); b) Cover Management Factor (C) 


\subsection{Supporting Conservation Practice Factor $(P)$}

The $P$ factor mainly represents how surface conditions affect the soil loss. This factor, also known as the support practice factor, reflects the effect of practices that will reduce the amount and rate of the water runoff and thus reduce the volume of erosion. The factor represents the ratio of soil loss with a specific conservation management practice to the corresponding soil loss with up and down the slope (Contour) tillage (Wischmeier \& Smith 1978; Renard et al. 1996; Dabral et al., 2008). Common support practices are: cross slope cultivation, contour farming, and strip cropping, terracing, and grassed waterways. In the present study, the P factor map was derived from the land use/ land cover and support assigned to areas with no conservation practices (mining and fallow land), and minimum values given to built-up land and Water body. It is spatial distribution map shown in Figure 7.

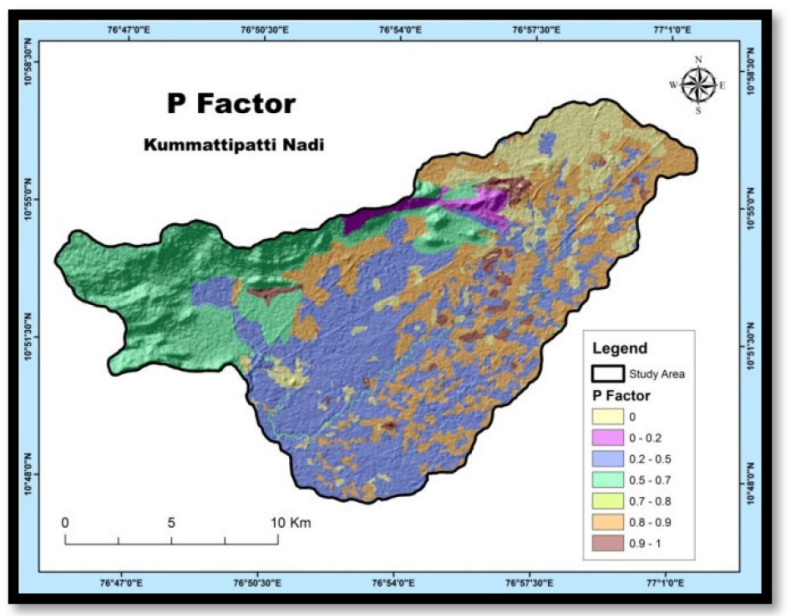

Figure 7. Supporting Conservation Practice factor (P)

\section{Annual average soil loss}

RUSLE is an empirically based model that has the ability to estimate the long term annual average rate of soil erosion on slopes. Data regarding 34 year rainfall data was used to estimate annual average rate of soil erosion, soil type and texture, topography and conservation management practices. All the RUSLE factors were multiplied using the empirical formula (Eq. (1)) and soil erosion was mapped. The potential annual soil loss is estimated from the product of factors ( $R, K, L S, C$ and $P$ ).

In this study final map represents the annual soil loss per hectare per year at pixel level. The soil loss values estimated for Kummattipatti Nadi watershed ranges from 0 to $153.7 \mathrm{tons} / \mathrm{ha} / \mathrm{yr}$ with an average of $53 \mathrm{t} / \mathrm{ha} / \mathrm{yr}$. The estimated pixel level soil loss value was grouped into five classes depending on the histogram distribution and the spatial distribution of soil loss is presented in Figure 8. These four classes are 1) High Erosion 2) Moderate Erosion 3) Marginal Erosion and 4) Low Erosion. The results presented in Table 3 show that, about $50.19 \%$ of the study area is classified as Low Soil Erosion risk. About 24.20\% and $18.90 \%$ of the study area is under the moderate and marginal soil erosion risk respectively. The spatial pattern of soil erosion classes indicate that the areas with high erosion risk are mainly located in the Boluvampatti which area has mostly hilly and steep slope. Also, another high soil erosion area has the one associated cement factory that lead to soil erosion.

Table 3. Soil erosion severity classes with average annual soil erosion rate

\begin{tabular}{|l|c|c|c|}
\hline $\begin{array}{c}\text { Soil erosion } \\
\text { Severity Class }\end{array}$ & $\begin{array}{c}\text { Annual average } \\
\text { soil erosion rate } \\
(\mathrm{t} / \mathrm{h}-1 / \mathrm{y}-1)\end{array}$ & $\begin{array}{c}\text { Area } \\
(\text { Sq. Km) }\end{array}$ & $\begin{array}{c}\text { Area } \\
(\%)\end{array}$ \\
\hline High Erosion & 40 and above & 17.75 & 6.71 \\
\hline Moderate Erosion & $(20-30)$ & 63.97 & 24.20 \\
\hline Marginal Erosion & $(10-20)$ & 49.96 & 18.90 \\
\hline Low Erosion & $(0-10)$ & 132.70 & 50.19 \\
\hline
\end{tabular}

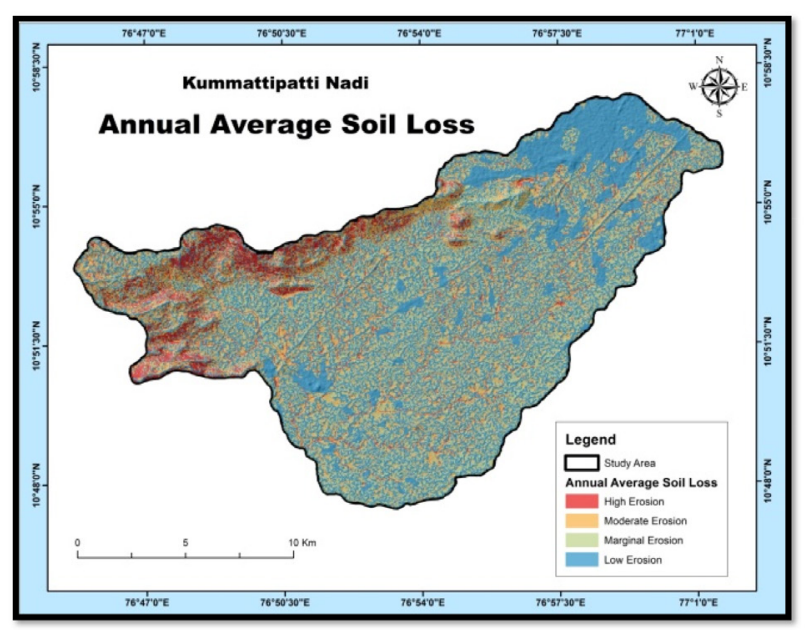

Figure 8. Annual average soil loss

\section{Conclusions}

This study determines the integration of RUSLE with GIS, to assess the soil erosion potential and find out the erosional risk. The widely used RUSLE model has been applied which has the thematic layers of (R, K, LS, C, and $\mathrm{P}$ ) were prepared by using the ArcGIS. These layers were overlaid in raster calculator by using the empirical equation (1) and a soil erosion map was generated which gave the spatial distribution of the potential soil erosion zones. It was observed that soil erosion was a prominent phenomenon in the seasonal river bodies and in vacant land, fallow land, wasteland, and agriculture fields. The hill top sloping area and area with mining activity faces severe soil erosion. In the foothill area slight erosion and marginal erosion has occurred. Since the area has a majority of agricultural fields and considerable amount of fallow land. All the agriculture fields located near the river sides must follow very serious and effective conservation practices. The wasteland and barren land should be used sustainable with some alternative cultivation practices. 


\section{References}

Angima, S. D., Stott, D. E., O’Neill, M. K., Ong, C. K., \& Weesies, G. A. (2003). Soil erosion prediction using RUSLE for central Kenyanhighland conditions. Agriculture, Ecosystems \& Environment, 97, 295-308.

https://doi.org/10.1016/S0167-8809(03)00011-2

Balasubramani, K., Veena Mohan, Kumaraswamy, K., \& Saravanabavan, V. (2015). Estimation of soil erosion in a semiarid watershed of Tamil Nadu (India) using revised universal soil loss equation (rusle) model through GIS. Modeling Earth Systems and Environment, 1, 10.

https://doi.org/10.1007/s40808-015-0015-4

Biesemans, J., Meirvenne, M. V., \& Gabriels, D. (2000). Extending the RUSLE with the Monte Carlo error propagation technique to predict long-term average oV-site sediment accumulation. Journal of Soil and Water Conservation, 55, 35-42.

Benkobi, L., Trlica, M. J., \& Smith, J. L. (1994). Evaluation of a re. ned surface cover subfactor for use in RUSLE. Journal of Range Management, 47, 74-78. https://doi.org/10.2307/4002845

Dabral, P. P., Baithuri, N., \& Pandey, A. (2008). Soil erosion assessment in a hilly catchment of North Eastern India using USLE, GIS and remote sensing. Water Resource Management, 22(12), 1783-1798.

https://doi.org/10.1007/s11269-008-9253-9

Desmet, P. J. J., \& Govers, G. (1996). A GIS procedure for automatically calculating the USLE LS factor on topographically complex landscape units. Journal of Soil and Water Conservation, 51(5), 427-433.

Dunn, M., \& Hickey, R. (1998). The effect of slope algorithms on slope estimates within a GIS, Cartography, 27(1), 9-15. https://doi.org/10.1080/00690805.1998.9714086

Foster, G. R., \& Wischmeier, W. H. (1974). Evaluating irregular slopes for soil loss prediction, Transactions of the American Society of Agricultural Engineers, 17(2), 305-309.

https://doi.org/10.13031/2013.36846

Hickey, R. (2000). Slope angle and slope length solutions for GIS. Cartography, 29(1), 1-8.

https://doi.org/10.1080/00690805.2000.9714334

Kouli, M., Soupios, P., \& Vallianatos, F. (2009). Soil erosion prediction using the revised universal soil loss equation (RUSLE) in a GIS framework, Chania, Northwestern Crete, Greece. Environmental Geology, 57(3), 483-497.

https://doi.org/10.1007/s00254-008-1318-9

Mhangara, P., Kakembo, V., \& Lim, K. (2012). Soil erosion risk assessment of the Keiskamma catchment, South Africa using GIS and remote sensing. Environmental Earth Science, 65(7), 2087-2102. https://doi.org/10.1007/s12665-011-1190-x

Moore, I., \& Burch, G. (1986). Physical basis of the length-slope factor in the Universal Sol Loss Equation. Soil Society of America Journal, 50, 194-1298. https://doi.org/10.2136/sssaj1986.03615995005000050042x

Parveen, R., \& Kumar, U. (2012). Integrated approach of universal soil loss Equation (USLE) and geographical information system (GIS) for soil loss risk assessment in Upper South Koel basin, Jharkhand. Journal of Geographic Information System, 4, 588-596. https://doi.org/10.4236/jgis.2012.46061

Prasannakumar, V., Vijith, H., Abinod, S., \& Geetha, N. (2012). Estimation of soil erosion risk within a small mountainous sub-watershed in Kerala, India, using revised universal soil loss equation (RUSLE) and geo-information technology. Geoscience Frontiers, 3(2), 209-215.

https://doi.org/10.1016/j.gsf.2011.11.003

Rahaman, S. A., Aruchamy, S., Jegankumar, R., \& Ajeez, S. A. (2015). Estimation of annual average soil loss based on RUSLE model in Kallar watershed, Bhavani basin, Tamil Nadu, India. ISPRS Annals Photogrammertry, Remote Sensing and Spatial Information Sciences, II-2/W2, 207-214.

https://doi.org/10.5194/isprsannals-II-2-W2-207-2015

Ranzi, R., Le T. H., Rulli, M. C. (2012). A RUSLE approach to model suspended sediment load in the Lo river (Vietnam): effects of reservoirs and land use changes. Journal of Hydrology, 422-423, 17-29. https://doi.org/10.1016/j.jhydrol.2011.12.009

Renard, K. G., \& Ferreira, V. A. (1993). RUSLE model description and database sensitivity. Journal of Environmental Quality, 22, 458-466.

https://doi.org/10.2134/jeq1993.00472425002200030009x

Renard, K. G., Foster, G. R., Weesies, G. A., McCool, D. K., \& Yoder, D. C. (1996). Predicting soil erosion by water: a guide to conservation Planning with the revised universal soil loss equation (RUSLE) (Agriculture Handbook No. 703). USA Department of Agriculture, Washington.

Sharma, A., Tiwari, K. N., \& Bhadoria, P. B. S. (2011). Effect of land use land cover change on soil erosion potential in an agricultural Watershed. Environmental Monitoring and Assessment, 173(1-4), 789-801.

https://doi.org/10.1007/s10661-010-1423-6

Schwab, G. O., Fangmeier, D. D., Elliot, W. J., \& Frevert, R. K. (1993). Soil and water conservation engineering (4 ed., pp. 68-91). John Wiley and Sons, Inc.

Shi, Z. H., Cai, C. F., Ding, S. W., Wang T. W., \& Chow, T. L. (2004). Soil conservation planning at the small watershed level using RUSLE with GIS: a case study in the Three Gorge area of China. Catena, 55(1), 33-48. https://doi.org/10.1016/S0341-8162(03)00088-2

Singh, G., Babu, R., Narain, P., Bhushan, L. S., \& Abrol, I. P. (1981). Soil loss prediction research in India (Bull. No. T12/D-9). Central Soil and Water Conservation Research Training Institute, Dehradun.

Van der Knijff, J. M., Jones, R. J. A., \& Montanarella, L. (2000). Soil erosion risk assessment in Europe (EUR 19044 EN). Ispra: European Soil Bureau, Joint Research Centre.

Van Remortel, R., Hamilton, M., \& Hickey, R. (2001). Estimating the LS factor for RUSLE through iterative slope length processing of digital elevation data. Cartography, 30(1), 27-35. https://doi.org/10.1080/00690805.2001.9714133

Vijith, H., Suma, M., Rekha, V. B., Shiju, C., \& Rejith, P. G. (2012). An assessment of soil erosion probability and erosion rate in a tropical mountainous watershed using remote sensing and GIS. Arabian Journal of Geosciences, 5(4), 797-805. https://doi.org/10.1007/s12517-010-0265-4

Wischmeier, W. H., \& Smith, D. D. (1978). Predicting rainfall erosion, soil losses, A Guide to conservation planning (Agriculture handbook No. 537). Department of Agriculture, USDA, Washington, DC.

Yang, D., Kanae, S., Oki, K., Koike, K., Musiake, K. (2003). Global potential soil erosion with reference to land use and climate changes. Hydrological Process, 17, 2913-2928.

https://doi.org/10.1002/hyp.1441 